\title{
Global Science Teaching for Human Well-Being
}

\author{
Rita Anastácio*, Ulisses M. M. Azeiteiro, Mário Jorge Pereira \\ Departamento de Biologia e CESAM, Universidade de Aveiro, Aveiro, Portugal \\ Email: ^rita_sofia@msn.com
}

How to cite this paper: Anastácio, R., Azeiteiro, U. M. M., \& Pereira, M. J. (2017). Global Science Teaching for Human WellBeing. Creative Education, 8, 2275-2292. https://doi.org/10.4236/ce.2017.814156

Received: October 6, 2017

Accepted: November 20, 2017

Published: November 23, 2017

Copyright $\odot 2017$ by authors and Scientific Research Publishing Inc. This work is licensed under the Creative Commons Attribution International License (CC BY 4.0).

http://creativecommons.org/licenses/by/4.0/

\begin{abstract}
A curriculum framework for seven years of science education is delivered as a proposal for discussion, for the nine years of schooling that the Incheon Declaration defines as compulsory (UNESCO, 2015). Every child should learn Science in their mother tongue, hence at least one global science curriculum should be provided for free, translated for free, and posted in a public site. The materials derived from the same curriculum should be provided with the same perspective: translated into the child's mother tongue, easily available and free. These derived materials should address as well the traditional/local knowledge, respecting indigenous cultures. We strongly believe that, to achieve the 2030 goals for education, a massive global act of passion altruism that puts each teacher and pedagogue's creativity at the service of global science teaching. For other subjects, the feeling and convictions are the same. But, because we all depend on ecosystems that sustain us, to deliver that message using a science curriculum is an obligation. Sharing a global science curriculum open to change and debate that conjugates Biology, Geology, Physics, and Chemistry, while having in consideration the sustainable development goals, is the aim of this manuscript.
\end{abstract}

\section{Keywords}

Science Curriculum, Human Well-Being, Sustainable Development Targets

\section{Introduction}

"Education is the most powerful path to sustainability. Economic and technological solutions, political regulations or financial incentives are not enough. We need a fundamental change in the way we think and act." (Bokova, 2012)

Ethics is, according Savater (1995), the art of living well, of knowing how to live. To have, practice, and manage the art of living well is ought to provide a 
good life. A good life implies choosing, which for those with less academic resources is more difficult (see IDSN, http://idsn.org/key-issues/education/). Our well-being depends on the existent biodiversity and on ecosystems' prosperity (MEA, 2005). However, people still choose to deplete natural resources, affecting other species, hence reducing biodiversity (Rands et al., 2010), and even annihilating it (see Ceballos et al., 2017).

The 2000-2010 decade was productive in ideas, congresses and documents about how the loss of biodiversity jeopardizes our future. It is the decade of the Millennium Development Goals (MDGs), and of the Millennium Ecosystems Assessment (MEA). The MEA (2005) highlights the fact that society does not understand completely how biodiversity and well-being are linked. Most people recognize that their lives depend on natural functions, which provide fresh water, food, shelter, fibers; but people take the benefits they take from Nature for granted (MEA, 2005).

In developed countries, schools teach how important it is to preserve biodiversity. Of course, in these countries, native biodiversity has been deeply affected by the development of societies through centuries (Despommier, 2010). We became aware of the importance of preserving forests, dealing with waste, and purifying water to drink (Despommier, 2010). Schools in developed countries have projects like ECO-SCHOOLS, http://www.ecoschools.global/, and most (if not all) subjects (English, Geography, History, Informatics, Mathematics, Natural Sciences, etc.) incorporate themes related with the Brundtland Report (1987) and the Agenda 21 (1992) themes. Whereas developed countries have been improving their school systems and acquiring experience in teaching and creating experiences related with biodiversity and sustainability, debating about science and ecology, which are complex issues for kids, teenagers and even adults (Vale, 2013; Nordlund, 2016), developing countries are struggling to bring more children to school, to build better schools, to train more teachers and to improve subjects' curricula (see "progress of goal 4 in 2017" at SDG 4 (2015) https://sustainabledevelopment.un.org/sdg4). Because people's future will depend on how they relate to ecosystems, it is urgent to provide strategies to empower teachers and learners on a global basis.

"Biodiversity change is (...) inextricably linked to poverty, the largest threat to the future of humanity identified by the United Nations (Díaz et al., 2006)."

The contribution done here addresses the concern of empowering society to understand the link between biodiversity and human well-being in such a way that almost every aspect of people's lives could be conducted by a better philosophy of choosing healthier ways of relating to ecosystems' functions, services and species. Our way of living is not yet oriented towards sustainability, and the only way to improve it is by reaching as many people as possible through education.

“(...) education is a public good, a fundamental human right and a basis for 
guaranteeing the realization of other rights. It is essential for peace, tolerance, human fulfillment and sustainable development." (UNESCO, 2015)

Science, as an institution, has been concerned with these issues and debates a way to "translate economic and socio-cultural values of ecosystems services into monetary values" (de Groot et al., 2010) to make people understand better its importance (Costanza et al., 1997). Science is still deciphering how biodiversity is linked to ecosystem services (Díaz et al., 2006; Rands et al., 2010), while the United Nations (UN) assesses governments on their efforts to reach Sustainable Development targets related to climate (SDG 13), biodiversity on land (SDG 15) and sea (SDG 14) goals, among others

(https://sustainabledevelopment.un.org/?menu=1300).

Planetary citizenship is also a well-known concept that emerged from a post-globalization world (Bindé, 2004) that is still being developed (by the SDGs). UNESCO established the creation of four contracts to build planetary citizenship values: The social contract, in which education should be viewed as a priority through life; The natural contract, which aimed at serving the human development, respecting ecosystems and species; The cultural contract, which debated cultural impacts; and The ethical contract, that aimed for the emergence of a global philosophy, in what concerns human well-being and sustainable development (Odhiambo in Bindé, 2004). Philosophers like Popper (1999), years before, struggled to build a global framework to end poverty and violence. Many (UN, UNESCO, UNICEF) believe that education is a strong tool to make a difference in building up a better planetary citizenship (UNESCO, 2015).

In this paper, it is aimed to make a specific contribution of a basic science global curriculum for seven years of school (from primary 3 to the ninth grade). It is also intended to debate the importance of providing a basic framework to guide science teaching from the third grade to the ninth grade; sometimes, instead of establishing an unachievable goal, to begin with a simpler solution can be better.

Education through life is also an ambitious goal, and, perhaps, still far from reach in many parts of our world. But, the effort of providing information to adults will help people ask more questions and search for answers. A basic curriculum for children can be used and adapted to adult's need of learning more about science.

"Education transforms lives and is at the heart of UNESCO's (2017) mission to build peace, eradicate poverty and drive sustainable development" http://en.unesco.org/themes/education-21st-century

\section{A Global Science Curriculum: A Framework for the First Nine Years of School}

The Incheon Declaration (UNESCO, 2015) emphasizes the need for "relevant teaching and learning methods and content that meet the needs of all learners, (...) using appropriate pedagogical approaches and supported by appropriate 
information and communication technology (ICT)", among other important issues. ICT, for example, are not available in every school, but education systems can deliver information to remote schools. Because of the urgency of providing "relevant content that meet the needs of all learners", we believe that a basic framework to teach and engage children, teenagers and adults (people are never too old to learn) in Science learning is fundamental. This curriculum, proposed here as a non-closed document, i.e. open to discussion, is ought to be translated and downloaded by any country that desires to use it. Also, the pedagogical approaches and materials derived from the curriculum should be available and translated for free in every language. This is the perspective we advocate.

We are mostly concerned with an "education for sustainable development" (ESD) that prepares children for problem solving, critical thinking and reflecting about issues that condition their lives (Vale, 2013). We want them to be aware of the fact that human beings are connected and depend on ecosystems and other species. We want them to be able to criticize and predict the consequences of human actions for the environment.

The framework shown here tried to intertwine information from several fields of Science, especially for the 7th, 8th and 9th grades of the curriculum. Repetition of information was avoided, thinking on the importance of providing a basic set of information to children that face the risk of quitting school earlier. We strongly recommend teachers to see this curriculum not as a "list of required topics and information" to pack in each school year (Vale, 2013), but as a guide to adapt to the context of each situation. We also emphasize the importance of the views shown in Vale's (2013) perspective, since allowing children to ask questions is allowing them "to promote independent learning".

The framework for the first years of school is shown in Table 1. We consider that Natural Sciences should be introduced as soon as possible. In fact, primary education in Singapore comprises Science as one of the core subjects for primary education, and they introduce it in primary 3 (Tan et al., 2016). The recommendation of starting with 8 years old is just because many schools do not have the means to keep young children for many hours learning, so they engage in teaching first native languages and mathematics. However, Science can be introduced even earlier (i.e. pre-school education). A connection between the themes and some of the SDGs was also taken in concern, and is pointed out in Table 1 and Appendix A.

For the 5th and 6th grades the complexity increases. The curriculum we propose is focused on understanding how science works and how ecosystems function. Conservation biology topics are explored (see Table A1 and Table A2. in Appendix A).

For the 7th, 8th and 9th grades abstract notions are added like: what were dinosaurs, how mountains are built, what is matter and energy, etc. Evolution, cell structure and metabolism, are examples of themes that should be developed (see Tables A3-A5 in Appendix A). 
Table 1. Natural Sciences curriculum themes for the first four years of school; Themes were distributed for the third and fourth years of primary school, but they can be distributed in other ways.

\begin{tabular}{l}
\hline \multicolumn{1}{c}{ Content } \\
\hline Ages $\mathbf{8}-\mathbf{9}$ (3rd grade, or primary 3) \\
Sustainable development goals (SDG) taken in consideration: 3,4
\end{tabular}

\section{Introduction to the study of Natural Sciences}

1). From a house to a planet

2). Living things (from macroscopic to microscopic scales) (biodiversity) SDG 14, 15

3). Natural Habitats for living things (species) SDG 14, 15

4). Transformed Habitats (crop fields, fish farms, ) SDG 14, 15

\section{Our relation with Nature SDG 11,12}

1) Living in rural areas versus living in urban areas

2) How to use habitats and nature causing less harm to other living beings?

\section{Theme 1.}

The idea is to explore different levels of nature occupancy, from what is familiar (house) to the explanation of where it belongs (Planet Earth). Then, it is aimed that children explore the different kinds of living things living in their environment, and develop their knowledge from that. It would benefit the development of the concept of biodiversity. Exploring, for example, that there are tiny living things like bacteria and protozoa; even if they cannot see them with microscopes, knowing the existence of microscopically living things opens the door for knowing and asking more.

\section{Theme 2}

The idea is to explore the different habitats near the school, and develop knowledge about different habitats for animals. It will set the basic ideas to explore the differences between living in rural areas and living in urban areas, and what that imposes to other species (plants and animals especially), like water, soil and air pollution, and habitat fragmentation. It is aimed to develop an "ecological conscience", or a "care moral" towards Nature and its living things.

Ages 9 - 10 (4th grade or primary 4)

Sustainable development goals taken in consideration: $2,3,4,5,6,11,12$

2. Our relation with Nature (cont.)
1) What are ecosystems?
2). Benefits and goods derived from
ecosystems
3). How do we affect ecosystems?
4). How does Nature affect us?
SDG $3,4,6,11$ (... sustainable), 12

\section{Our relation with Nature (cont.)} ecosystems

4). How does Nature affect us?

SDG 3, 4, 6, 11 (... sustainable), 12

\section{Theme 2. (cont.)}

After understanding that people belong to Nature, like every other species, and knowing the variety of natural habitats, the word "ecosystem" is ought to be explored. Showing examples of how abiotic and biotic factors influence each other, and how they become part of bigger units-the ecosystems. What is intended is not the rigid use of the correct words (like ecosystem, abiotic factor, etc.) but to mobilize ideas like: light affects animals' behavior (and explore examples),

water is essential for all living things (animals drink fresh water, plants need water and it is an important part of the water cycle); people need to extract wood from the forest, but what does that entail, etc. 


\section{Continued}

\section{Human health and care}

1). The human body: how it grows (baby, child, teenager, adult) and gender characteristics

2). Hygiene

3). Food and nutrition

4). Tackling diseases

5). What is needed for human well-being?

SDG 2, 3, 5, 6, 12 (... sustainable consumption)
Theme 3.

We advise focusing on human beings, by studying their body only after the previous themes have been explored. The theme "how it grows and gender differences" is ought to explore reproduction, development and differences between boys and girls adequately to this level. This is an opportunity to empower girls. It is important to emphasize that each person has different abilities that should be respected, addressing also that some children have special needs (creating awareness and tolerance).

The "Hygiene" topic should explore the importance of water security, disinfection of hands, bathing and cleaning. But also, how water can be disinfected or even not polluted. The "Food and nutrition" theme ought to explore food security, but also strategies to help children feed better and make better choices for their health. The "Tackling diseases" subtheme should prepare children in poor countries with poor sanitation facilities to cope with that context, and deal with strategies to avoid being ill. The importance of vaccination, hygiene and protective behaviors should be taught. The categories of human well-being should be explored in the end as a goal to reach through every person's life and because it relates to the World Health Organization's (WHO) "human health" concept.

To develop materials for or derivations of this (or other) curriculum, we emphasize the importance of learning in a "safe, healthy, gender-responsive, inclusive and adequately resourced environment" (UNESCO, 2015), as much as possible. What is encouraged is a state of mind of "Teach Less, Learn More", following Singaporean ideology (Tan et al., 2016).

\section{Discussion}

Education about conservation ecology is important to improve human relation with natural goods and benefits. Only through education will it be possible to improve the human relationship with ecosystems. The public and governments' interest in reverting the pressures on wild species is increasing, as Rands et al. (2010) emphasize, but not effectively to halt biodiversity loss (Ceballos et al., 2015, 2017). Perhaps due to the fact that, like climate change, ecology's complexity demands more understanding and compliance from governance and policy, sponsors, markets, education systems, and from common people. 
"Education systems must be relevant and respond to rapidly changing labour markets, technological advances, urbanization, migration, political instability, environmental degradation, natural hazards and disasters, competition for natural resources, demographic challenges, increasing global unemployment, persistent poverty, widening inequality and expanding threats to peace and safety." (UNESCO, 2015).

Marine turtles, for example, subjects of many conservation projects have a strong impact on tourists and local people, especially children. But the local children are confronted with mixed feelings: turtles must be protected to ensure monetary revenue by tourism (upon which many families rely), but turtles are also explored and pressured by being advertised by locals. This is what happens, for example in Quintana Roo, México despite the efforts of non-governmental organizations like "Centro Ecológico Akumal" (http://www.ceakumal.org/), that develop environmental education activities for children. And this is only an example that involves emblematic species and their delicate habitats and niches (the nesting beaches used by females, the sea grass beds and the corals explored by the juveniles in the coast).

Human-wildlife conflicts-another example-show the complexity of the human need to use ecosystems and compete with other species. For humans, other species have different value. Some are just to contemplate, while others provide material goods (many of which have been prohibited to collect).

Elephants are poached because of their ivory (Goldenberg et al., 2016), and though it is prohibited to hunt them, many poachers still take the risk, because of the profit generated in the market (Goldenberg et al., 2016). Many elephants are also killed because they are feared and destroy goods (Taruvinga \& $\mathrm{Mu}-$ shunje, 2014; Anastácio et al., 2014). But in all cultures they are seen as symbols of nature, used as flagship species (Lee \& Graham, 2006). Beyond the problems they cause, elephant's species are gardeners of the ecosystems (Douglas-Hamilton et al., 2005), and they are classified as keystone species (Meffe \& Carroll, 1997; Thouless et al., 2016), hence, they play an important role in the ecosystems, which humans cannot afford to lose. The example of elephants' relation with humans poses a great challenge to all of us. How can poor people live and share resources with these big and charismatic creatures? Elephants' spots and home ranges are being invaded by people in worryingly increasing numbers, and conflicts happen frequently, ending in people or elephant deaths (Douglas-Hamilton et al., 2005; Pinter-Wollman, 2012; Taruvinga \& Mushunje, 2014), even inside protected areas (Craig, 2013). So, how can this problem be dealt with from an educational perspective? Can it be separated from an ecological/conservation perspective? Can the biological perspective be separated from the social point of view? It seems like it cannot (Bradshaw \& Bekoff, 2001). Conservation ecology is a multidisciplinary field that depends on understanding peoples' beliefs and needs (sociology, anthropology), how ecosystems function (ecology, biology), and how society experiences their time and space (economics, political science, 
communication science, education science) (Meffe \& Carroll, 1997).

What can we do, as a global society, to help preserve species like elephants, and people? What can we teach and inform people about that would make a difference? We can prepare people to debate the dilemma by going to school. The Incheon Declaration (UNESCO, 2015) has the ambition of ensuring "the provision of 12 years of free, publicly funded, equitable quality primary and secondary education, of which at least nine years are compulsory, leading to relevant learning outcomes." A general science curriculum for the first nine years of school that emphasizes themes related with human well-being and ecosystems conservation, that enables the debate of complex questions like "what can we do to mitigate ivory poaching?" is, in our belief, a strong strategy. It is expected to be available online, but also in the form of didactic materials, for teachers to use them. Instead of waiting for each country to define standards and review curricula, UNESCO can provide, for each subject, a basic curricula for each grade, and from it, each country can adapt it to "ensure quality and relevance to the context, including skills, competencies, values, culture, knowledge and gender responsiveness" (UNESCO, 2015). For example, in the absence of a solution, the Ministry of Education of each country can start to translate and adapt the basic science curriculum, for every language spoken in the country, and upload their versions in the web. Only by sharing educational resources and experiences is it possible to transform lives in an effective way. And the attitude of sharing freely and offering pedagogical materials can help achieve a holistic development of competencies, like critical thinking, creativity and divergent thinking, communication, collaboration, independent learning, lifelong learning, and the most important of all, active citizenship (Tan et al., 2016), and global citizenship, and critical questioning (Vale, 2013).

Singapore, one of the most successful stories of growth, invested in its educational system in such a way that it constitutes an example that is still seeking, today, ways of improving and of breaking with a homogeneous rigid system (though effective) to become more heterogeneous, enabling their students to discover themselves by also developing soft skills (OECD, 2010; Gopinathan, 2011; Tan et al., 2016).

UNESCO has started the "sharing" effort with the "Open Educational Resources" (UNESCO-OER, 2017), or by creating the International Bureau of Education (IBE) (a global center of excellence in curriculum, at http://www.ibe.unesco.org/en/who-we-are). Also, initiatives like PISA4U (https://www.pisa4u.org/), which started in 2017, and even sites like https://www.oercommons.org/, or BBC Bitesize

http://www.bbc.co.uk/education/subjects/zng $4 \mathrm{~d} 2 \mathrm{p}$ constitute solid examples of what is intended. We believe that these platforms and projects would benefit from more simplicity (pages are a bit confusing, with immense information). Sharing what we know and how we know it for free is one of the most valuable gestures for the future of all living things. 
Other aspects are needed, like improving the preparation of teachers, or supervising pair work, choosing the most gifted for the job. However, considering that a country does not have enough teachers, at least every person with university or even secondary graduations can, if guided, help in the first years of education to expand the network of schools and achieve the SDGs 4, 5, and 10. In Portugal many engineers started to teach Mathematics, Physics or Chemistry in public schools after the 1974 Revolution, and many found a passion for teaching. It also happened with Biologists, who became great Biology teachers. Later, these "teachers" had to become specialized in education, and they embraced the teaching career, instead of the technical and industrial purpose for which they were prepared. If people have the proper orientation (e.g. clear curricula and materials), and the values that guide a teacher's activity, many can transform themselves into marvelous teachers. How many retired engineers, industry leaders, attorneys, investigators etc. in many countries can help teaching children as volunteer work? We comprehend that a country without enough teachers has to make a plan. Other measures have to be taken: if there is no money to train teachers, is it possible to train people in a specific area, whilst providing knowledge for that same person to be able to teach in a public school? Is it possible to have more than one profession in our lives? Is it possible to invest more in education and train more teachers? Is it possible to, after that, take the step of increasing teachers' pay? Poor countries need to be creative in finding solutions. Rich countries need to be supportive and share know-how. For now, our concern is delivering a curriculum for seven years of schooling that conjugates Physics, Chemistry, Biology and Geology in one single subject: Natural Sciences.

\section{Conclusion}

To make a difference in a child's life is to empower that child to become free to choose and act, feel and seek security in the environment, have access to basic materials, healthcare and information in a society that enables good social relations among people and that respects ecosystems and other species (MEA, 2005). Educating children from an early age in Science themes will increase their capacity to ask important questions, and to seek answers through their adult life. The Incheon Declaration has the goal of providing nine years of quality education to every child in the World. Whereas some countries have the means and the experience of good practices, underdeveloped countries struggle with many problems, including having a task force which is either unprepared or not large enough to guarantee nine years of studying for every girl and boy.

\section{References}

Agenda 21 (1992). http://www.onu.org.br/rio20/img/2012/01/agenda21.pdf

Anastácio, R. S., Schertenleib, L. N., Paiva, J., Ferrão, J., \& Pereira, M. J. (2014). Bottom-Up Approach towards a Human Wellbeing Assessment for the Design of a Management Plan: A Study Case with Contributions to Improve Sustainable Management of Resources in a Northern Area of Mozambique. Open Journal of Ecology, 4, 1102-1127. 
https://doi.org/10.4236/oje.2014.417090

BBC Bitesize, Science (2017). http://www.bbc.co.uk/education/subjects/zng4d2p

Bindé, J. (2004). General Introduction. In Where Do the Values Go? Debates of the 21st Century (pp. 21-28). Lisboa: Instituto Piaget.

Bokova, I., Director-General of UNESCO (2012). http://unesdoc.unesco.org/images/0021/002167/216708E.pdf

Bradshaw, G. A., \& Bekoff, M. (2001). Ecology and Social Responsibility: The Re-Embodiment of Science. Trends in Ecology \& Evolution, 16, 460-465. https://doi.org/10.1016/S0169-5347(01)02204-2

Brundtland Report (1987). http://www.un-documents.net/our-common-future.pdf

Ceballos, G., Ehrlich, P. R., Barnosky, A. D., García, A., Pringle, R. M., \& Palmer, T. M. (2015). Accelerated Modern Human-Induced Species Losses: Entering the Sixth Mass Extinction. Science Advances, 1, e1400253. https://doi.org/10.1126/sciadv.1400253

Ceballos, G., Ehrlichb, P. R., \& Dirzob, R. (2017). Biological Annihilation via the Ongoing Sixth Mass Extinction Signaled by Vertebrate Population Losses and Declines. Proceedings of the National Academy of Sciences of the United States of America, 114, E6089-E6096. https://doi.org/10.1073/pnas.1704949114

Centro Ecológico Akumal (2017). http://www.ceakumal.org/

Costanza, R., d'Arge, R., Groot, R., Farber, S., Grasso, M., Hannon, B., Limburg, K., Naeem, S., O’Neill, R. V., Paruelo, J., Raskin, R. G., Sutton, P., \& van den Belt, M. (1997). The Value of the World's Ecosystem Services and Natural Capital. Nature, 387, 253-260. https://doi.org/10.1038/387253a0

Craig, G.C. (2013). Aerial Survey of Quirimbas National Park and Adjoining Areas (Report). WWF, Mozambique Country Office.

de Groot, R. S., Alkemade, R., Braat, L., Hein, L., \& Willemen, l. (2010). Challenges in Integrating the Concept of Ecosystem Services and Values in Landscape Planning, Management and Decision Making. Ecological Complexity, 7, 260-272. https://doi.org/10.1016/j.ecocom.2009.10.006

Despommier, D. (2010). The Vertical Farm: Feeding the World in the $21^{\text {st }}$ Century. New York: Picador, $311 \mathrm{p}$.

Díaz, S., Fargione, J., Chapin III, F. S., \& Tilman, D. (2006). Biodiversity Loss Threatens Human Well-Being. PLoS Biology, 4, 1300-1305. https://doi.org/10.1371/journal.pbio.0040277

Douglas-Hamilton, I., Krink, T., \& Vollrath, F. (2005). Movements and Corridors of African Elephants in Relation to Protected Areas. Naturwissenschaften, 92, 158-163. https://doi.org/10.1007/s00114-004-0606-9

Eco-Schools, UNEP, UNESCO, UNWTO (1992). http://www.ecoschools.global/

Goldenberg, S. Z., Douglas-Hamilton, I., \& Wittemyer, G. (2016). Vertical Transmission of Social Roles Drives Resilience to Poaching in Elephant Networks. Current Biology, 26, 75-79. https://doi.org/10.1016/j.cub.2015.11.005

Gopinathan, S. (2011). The Education System in Singapore: The Key to its Success. National Institute of Education.

http://www.fedea.net/politicas-educativas/The_Education_System_in_Singapore_The Keyto_its_Success.pdf

International Bureau of Education (2017). http://www.ibe.unesco.org/en

International Dalit Solidarity Network, IDSN. http://idsn.org/key-issues/education/ 
Lee, P. C., \& Graham, M. D. (2006). African Elephants Loxodonta africana and Human-Elephant Interactions: Implications for Conservation. International Zoo Yearbook, 40, 9-19. https://doi.org/10.1111/j.1748-1090.2006.00009.x

Meffe, G. K., \& Carroll, C. R. (Eds.) (1997). Principles of Conservation Biology (2nd ed., pp. 3-27). Sunderland, Massachusetts: Sinauer Associates Inc.

Millennium Ecosystem Assessment (MEA) (2005). Ecosystems and Human Well-Being: Biodiversity Synthesis. Washington DC: World Resources Institute. https://www.millenniumassessment.org/documents/document.354.aspx.pdf

Nordlund, L. M. (2016) Teaching Ecology at University-Inspiration for Change. Global Ecology and Conservation, 7, 174-182. https://doi.org/10.1016/j.gecco.2016.06.008

Odhiambo, T. in Bindé, J. (2004). Ch. 2: The Future of Biodiversity. In Where Do the Values Go? Debates of the 21st Century (pp. 263-268). Lisboa: Piaget Institute.

OECD, Singapore (2010). Rapid Improvement Followed by Strong Performance. In Strong Performers and Successful Reformers in Education: Lessons from PISA for the United States. https://www.oecd.org/countries/singapore/46581101.pdf

Open Educational Resources, OER Commons (2007-2017). https://www.oercommons.org/

Pinter-Wollman, N. (2012). Human-Elephant Conflict in Africa: The Legal and Political Viability of Translocations, Wildlife Corridors, and Transfrontier Parks for Large Mammal Conservation. Journal of International Wildlife Law \& Policy, 15, 152-166. https://doi.org/10.1080/13880292.2012.678793

PISA4U, Programme for International Student Assessment, developed by the Organisation for Economic Co-Operation and Development (OECD) in Collaboration with CANDENA (2017). https://www.pisa4u.org/

Popper, K. R. (1999). All Life Is Problem Solving. A Vida é aprendizagem-epistemologia evolutiva e sociedade aberta. Edições, 70, 171-186.

Rands, M. R. W., Adams, W. M., Bennun, L., Butchart, S. H. M., Clements, A., Coomes, D., Entwistle, A., Hodge, I., Kapos, V., Scharlemann, J. P. W., Sutherland, W. J., \& Vira, B. (2010). Biodiversity Conservation: Challenges beyond 2010. Science, 329, 1298-1303. https://doi.org/10.1126/science.1189138

Savater, F. (1995). Ethics for a Young Person (3 ${ }^{\text {rd }}$ ed.). Lisboa: Editorial Presença.

SDG 4, SUSTAINABLE DEVELOPMENT GOAL 4 (2015). Ensure Inclusive and Equitable Quality Education and Promote Lifelong Learning Opportunities for All. https://sustainabledevelopment.un.org/sdg4

Tan, C., Koh, K., \& Choy, W. (2016). The Education System in Singapore. In S. Juszczyk, (Ed.), Asian Education Systems (pp. 129-148). Toruñ: Adam Marszalek Publishing House. https://www.researchgate.net/publication/311992398

Taruvinga, A., \& Mushunje, A. (2014). Society's Perceptions of African Elephants and Their Relative Influence towards the Conservation of Elephants. APCBEE Procedia, 10, 299-304. https://doi.org/10.1016/j.apcbee.2014.10.056

Thouless, C. R., Dublin, H. T., Blanc, J. J., Skinner, D. P., Daniel, T. E., Taylor, R. D., Maisels, F., Frederick, H. L., \& Bouché, P. (2016). African Elephant Status Report 2016: An Update from the African Elephant Database (vi+ 309 p). Occasional Paper Series of the IUCN Species Survival Commission, No. 60 IUCN/SSC Africa Elephant Specialist Group. Gland: IUCN.

UN Sustainable Development Goals (SDG), Sustainable Development Knowledge Platform (2015). https://sustainabledevelopment.un.org/?menu=1300 
UNESCO (2015). SDG4-Education 2030, Incheon Declaration (ID) and Framework for Action. For the Implementation of Sustainable Development Goal 4, Ensure Inclusive and Equitable Quality Education and Promote Lifelong Learning Opportunities for All, ED-2016/WS/28.

UNESCO (n.d.) Education for the 21st Century. http://en.unesco.org/themes/education-21st-century

UNESCO, OER (2017). What Are Open Education Resources (OERs)? http://www.unesco.org/new/en/communication-and-information/access-to-knowledge lopen-educational-resources/what-are-open-educational-resources-oers/

Vale, R. D. (2013) The Value of Asking Questions. Molecular Biology of the Cell, 24, 680-682. https://doi.org/10.1091/mbc.E12-09-0660 


\section{Appendix A}

The global Natural Sciences Curriculum is open to discussion and it is not a perfect scheme. It intends to conjugate Biology, Geology, Physics and Chemistry in a single framework. This framework was built having in consideration the SDG 4, through which it is possible to achieve the SDG 1.

To build up the following curricula the authors studied the science curricula from Portugal (RA applied the Portuguese Natural Sciences Curriculum several years, as a teacher-5th to 9th grades and 10th - 12th grades biology/geology curriculum), Mozambique (to which the authors had access), United States and U.K. (K-12)-available in the internet.

Several recent Biology, Geology, Chemistry and Physic books were used, to prepare a logical perspective of the themes.

Table A1. Proposal for fifth grade natural science curriculum.

\begin{tabular}{|c|c|c|}
\hline Theme & Subthemes & Intended outcomes \\
\hline \multicolumn{3}{|c|}{$5^{\mathrm{TH}}$ GRADE } \\
\hline Sustainable development $g$ & leration: 4,5 , & $, 14,15$ \\
\hline Science and its principles & $\begin{array}{l}\text { Unit 1. Science and } \\
\text { scientists } \\
\text { 1) Fields of Science: } \\
\text { Biology, Geology, Chemistry, } \\
\text { Physics, and other fields } \\
\text { 2) Brief history of Science } \\
\text { 3) What are } \\
\text { the characteristics of } \\
\text { investigators, researchers, } \\
\text { and scientists? } \\
\text { 4) Words in Science } \\
\text { (e.g. Latin use in Biology) }\end{array}$ & $\begin{array}{l}\text { Unit } 1 . \\
\text { To show what Science is, } \\
\text { and examples of its fields; } \\
\text { To tell the story of } \\
\text { Science, showing that } \\
\text { it is always evolving and } \\
\text { that there were obstacles; } \\
\text { To show that Science and } \\
\text { Technology made the world } \\
\text { easier for human beings to } \\
\text { live in, but brought problems; } \\
\text { To show that researchers are } \\
\text { common people with curiosity } \\
\text { (a researcher can be invited } \\
\text { to talk with children, } \\
\text { for example). } \\
\text { To explain the difference } \\
\text { between species' common } \\
\text { and scientific names. }\end{array}$ \\
\hline Lab and Field work & $\begin{array}{l}\text { Unit 2. Working in a } \\
\text { Laboratory and in the } \\
\text { Field (Nature) } \\
\text { 1) Rules to work in a } \\
\text { Lab (show and/or practice) } \\
\text { 2) Lab equipment } \\
\text { (show and/or practice, } \\
\text { if possible) } \\
\text { 3) Rules to work in the } \\
\text { field (show and practice) } \\
\text { 4) Field equipment (show } \\
\text { and practice) }\end{array}$ & $\begin{array}{l}\text { Unit } 2 . \\
\text { To prepare children to } \\
\text { work in small groups } \\
\text { with simple experiments } \\
\text { To develop lab and field work } \\
\text { skills by collecting plants, } \\
\text { or organizing an experiment, } \\
\text { or observing bugs with } \\
\text { magnifying glasses, etc. } \\
\text { The idea is to develop } \\
\text { autonomy, joy of observing } \\
\text { and experimenting, } \\
\text { organization, and } \\
\text { communication skills } \\
\text { (by drawing, explaining, etc.) }\end{array}$ \\
\hline
\end{tabular}




\section{Continued}

$\begin{array}{ll}\text { Biology } & \text { Unit 3. Diversity of life } \\ \text { Biodiversity } & \text { 1) Living things are grouped } \\ \text { Taxonomy } & \text { into Kingdoms: } \\ & \text { Monera, Protista, } \\ & \text { Fungi, Animalia, Plantae }\end{array}$

Unit 3.

To create awareness for the diversity that exists around us, even if we do not see it, and the need for organizing it in groups.

To show examples of species from all kingdoms.

The cell

Monera

Protista

Fungi

Plantae

Animalia

Human beings: a particular case
2) Unit of living things: the cell

3) Cell Theory (basic principles)

4) Knowing about bacteria (using a microscope) 5) Knowing about Protista (in a drop of water, for example; observe Algae)

6) Knowing about Fungi (yeast cells, molds, mushrooms, etc.)

7) Different plants a) Structure of a plant (angiosperm, for example)

8) Knowing about animals (sponges, cnidarians, mollusks, arthropods, fish, amphibians, reptiles, birds and mammals)

a) Structure of a mammal
To explain what is a cell and that there are 3 different types of cells (prokaryotic and eukaryotic animal and plant cells); Show examples of cells (with images, experiments, etc.); To explore notions like unicellular, multicellular organisms, and biological levels of complexity (cell-tissue-organ-system of organs-individual). To observe living beings from the children's context and knowing about their diversity. To make experiments and record observations (see examples):

- infusion to observe protozoa,

- collect algae and observe,

- observe molds,

- use yeast to make bread,

- collect and observe plants and their parts (root, stem, leaves, flowers, fruits, seeds),

- collect little bugs and drawing them without harming (pill bugs, for example), or dead bugs to observe and draw (bees, ...).

To explore videos, the internet and books about living beings.

\section{Unit 4.}

To explain the human body and its systems (using figures, schemes, videos, etc.)

To explain the menstrual cycle to boys and girls (at this age it is of major importance, especially for girls). 
Table A2. Proposal for sixth grade natural science curriculum.

\begin{tabular}{|c|c|c|}
\hline Theme & Subthemes & Intended outcomes \\
\hline \multicolumn{3}{|l|}{$6^{\mathrm{TH}}$ GRADE } \\
\hline \multicolumn{3}{|c|}{ Sustainable development goals taken in consideration: $2,3,4,5$} \\
\hline Ecology & $\begin{array}{l}\text { Unit } 5 . \text { Home for the living } \\
\text { things }\end{array}$ & Unit 5. \\
\hline \multirow[t]{15}{*}{ Ecosystems services } & $\begin{array}{l}\text { 1). Ecosystem definition } \\
\text { and examples }\end{array}$ & $\begin{array}{l}\text { To understand what an } \\
\text { ecosystem is, and study }\end{array}$ \\
\hline & 2). Abiotic factors & examples. \\
\hline & (wind, water, substrate, & To explore different \\
\hline & temperature, pressure, & abiotic factors (and make \\
\hline & light, salinity) & simple experiments). \\
\hline & 3). Habitats and niches & To acquire the notion of habitat \\
\hline & 4). Atmosphere, & and niche of a species. \\
\hline & $\begin{array}{l}\text { hydrosphere, geosphere } \\
\text { and biosphere }\end{array}$ & $\begin{array}{l}\text { To understand the connectivity } \\
\text { between ecosystems, and the }\end{array}$ \\
\hline & 5). Ecosystem services (food & atmo/geo/hydro/biospheres. \\
\hline & and water provisioning, air & To explore simple examples \\
\hline & quality regulation, & of important services \\
\hline & climate regulation, waste & provided by ecosystems. \\
\hline & regulation and treatment, & \\
\hline & soil formation, climate & \\
\hline & regulation, pollination, etc.) & \\
\hline \multirow{15}{*}{$\begin{array}{l}\text { Ecology: Flow of } \\
\text { energy and matter } \\
\text { in an ecosystem }\end{array}$} & Unit 6. Food and Energy & Unit 6. \\
\hline & $\begin{array}{l}\text { 1). Producers (phototrophs } \\
\text { and chemotrophs) }\end{array}$ & $\begin{array}{l}\text { To learn the role of organisms in } \\
\text { the flow of energy and matter }\end{array}$ \\
\hline & 2). Consumers & circulation inside the ecosystem. \\
\hline & (heterotrophs) & To explore how human activities \\
\hline & 3). Decomposers & interfere with the food webs and \\
\hline & 4). Food chains, food webs, & how that jeopardizes food \\
\hline & flux, and matter cycle. & To know and debate the \\
\hline & 5). How can human activities & fragmentation of habitats. \\
\hline & disrupt food webs? & To know farming practices used \\
\hline & 6). Consequences of energy & in the region, and sustainable \\
\hline & and matter flow disruptions & farming practices. \\
\hline & for the ecosystems & To know fishing practices \\
\hline & 7). Farming and & used in the region, and \\
\hline & Fishing—the "dos" & sustainable fishing practices. \\
\hline & and the "don'ts" & \\
\hline
\end{tabular}


Table A3. Proposal for seventh grade natural science curriculum.

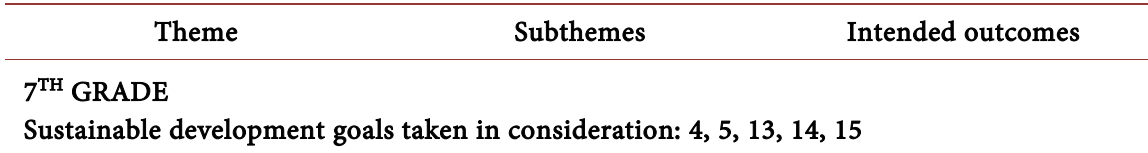

Evolution
Palaeontology
Tectonics
Geologic time
Mass Extinction

Unit 7. Earth's evolution

and Biodiversity

1) Why are livings things so diverse?

2) Were there different

living things on Earth?

3) Charles Darwin and

the Evolution theory

4) Fossils and sedimentary

rocks

5) Why did such an amount

of species become extinct?

a) The sixth Mass

extinction: causes

and consequences

6) Earth's age and

geologic time divisions

7) Earth's transformations

through time:

- atmosphere

- $\quad$ surface dynamisms (volcanoes, earthquakes)

- interior of the Earth

8) Plate tectonics

9) The diversity of

landscapes, and their

biological and aesthetic values
Unit 7.

To learn about the diversity of species and develop

questioning and

debate about it

Introduce Darwin and

Wallace, and their process on developing evolution theory.

To learn what a fossil

\section{species is}

To debate and question about natural extinctions, and anthropogenic causes that lead to species' extinction. To develop the notion of geologic time.

To explore Earth's dynamism with atmosphere, surface and interior phenomena.

To explore Plate tectonics (geology science), that explains the importance of geographic barriers for the evolution of species. To show and study the richness of different landscapes, and their importance. 
Table A4. Proposal for eighth grade natural science curriculum.

\begin{tabular}{ll}
\hline \multicolumn{1}{c}{ Theme } & Subthemes \\
\\
$8^{\mathrm{TH}}$ GRADE \\
Sustainable development goals taken in consideration: & $4,5,12,13,14,15$
\end{tabular}

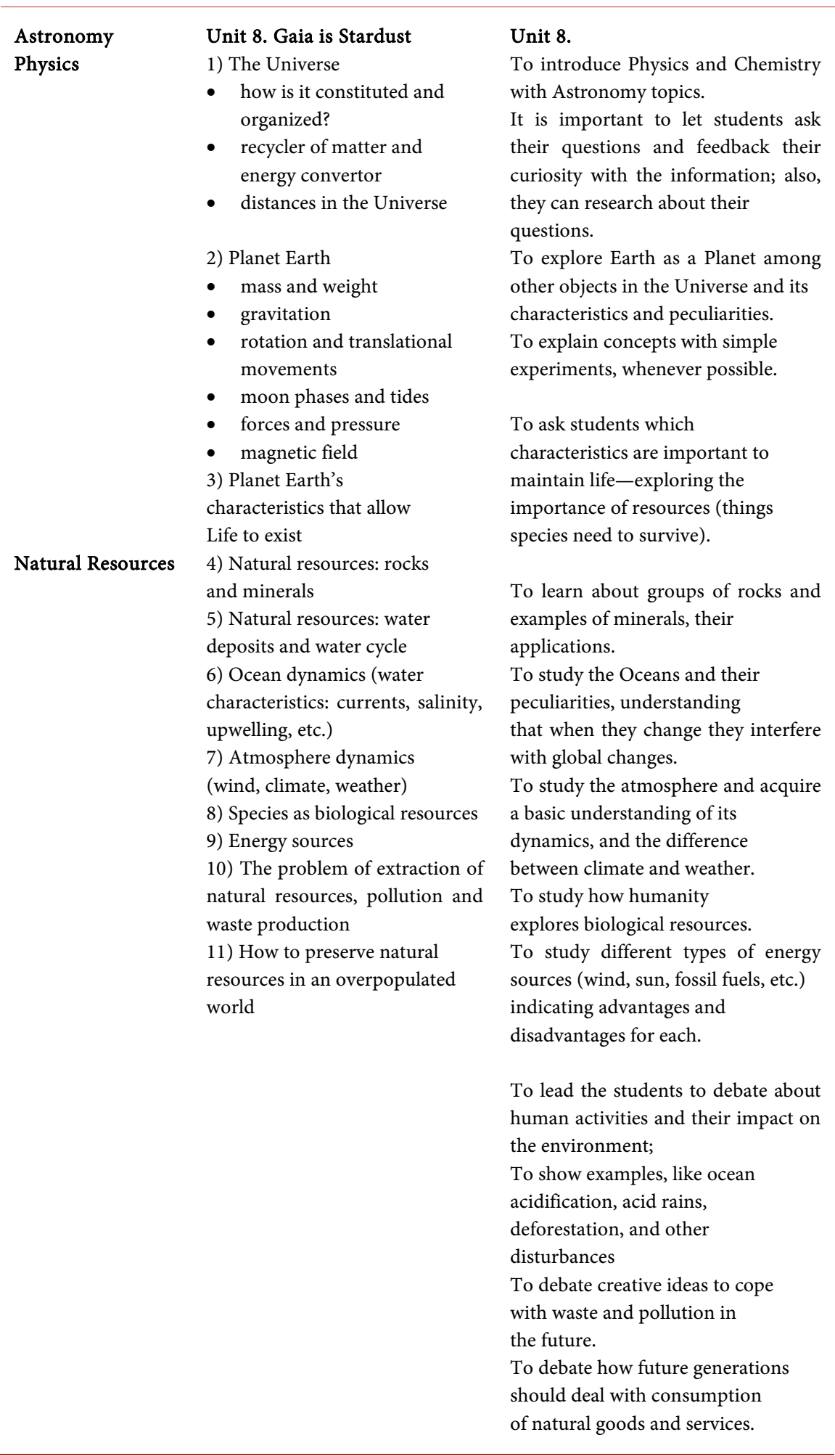


Table A5. Proposal for ninth grade natural science curriculum.

\begin{tabular}{|c|c|c|}
\hline Theme & Subthemes & Intended outcomes \\
\hline
\end{tabular}

\begin{tabular}{ll}
\hline Physics & $\begin{array}{l}\text { Unit 9. The complexity } \\
\text { of Nature }\end{array}$ \\
& 1) Energy \\
2) Light and colour & 3) Sound \\
4) Matter & - Periodic table \\
& - Elements, atoms and \\
& - Chemical reactions \\
Cell Structure & 5) The cell structure \\
and Metabolism & 6) Cell metabolism: what is it? \\
- Photosynthesis purpose \\
- Fermentation purpose \\
- Aerobic respiration purpose \\
- DNA expression \\
7) Cell cycle and mitosis \\
8) Meiosis and fecundation \\
9) The Immune system
\end{tabular}

Recommendations:

Themes should be developed to provide the basic information to understand how nature works. It is not intended to massacre students with formulas and definitions, but to let them hear and ask about what is energy, light (why are plants' foliage green), etc.

The ideal would be for natural sciences to have 3 to 4 hours per week in students' schedule, but, that is not the reality of many places, so teachers need to seek the best way to explain the topics as efficiently as possible, but without suffocating students.

This applies to all the themes shown. For example, if teachers have time, they can explain the implications of meiosis and fecundation for the diversity of life, and even explore different life cycles; Otherwise, they can show meiosis as a different process for genetic material division of the cell.

An idea is to use the Immune system as the central theme to mobilize the information taught in Unit 9.

To learn concepts of Physics like energy, light, and sound. To learn about the organization of matter.

To learn the cell structure: organelles and their functions and interactions To study some metabolic pathways/purposes, like photosynthesis, fermentation, cell respiration and genetic expression. To learn the cell cycle and mitosis (with microscopic observations whenever possible).

To learn meiosis and fecundation, and the implications of them.

To study the human immune system, as a complex interaction between tissues, cells, molecules of a wide variety. 